\title{
Revisiting Academic Capitalism in Turkey: An Interactional Model for University-Industry Collaboration
}

\author{
By Secil Dayioglu Ocal \\ Yuksel Kavak ${ }^{\dagger}$
}

Due to the knowledge economy and its impacts on collaborative works with industry, universities have been obliged to shift themselves into entrepreneurialism. This has a great impact on research and development activities and brings about change in structural and cultural academia and institutions, i.e. academic capitalism. This study is based on secondary data analysis of the qualitative study conducted to seek the university-industry relations in three technocenters at Hacettepe University, Middle East Technical University, and Bilkent University, Ankara, Turkey in 2011. This study aims at revisiting academic capitalism with regard to an interaction model based on the findings of that qualitative study. The participants of that study were fifteen executives of the companies in the field of education. The data were gathered through interviews and analyzed via content analysis. The model discusses the actors, their interaction and their roles, tasks and duty in this collaboration. It is considered that this model empowers the collaboration between the university and the industry and triggers more collaborative works.

Keywords: Academic capitalism, university-industry collaboration, higher education, model design, university administration.

\section{Introduction}

Universities are major drivers for innovation and local, regional and national economic development in the information age. Industry can produce high-tech and innovative products based on academic researches. This brings about the concept of university-industry collaboration, which is defined as:

"an activity in which firms learn from experience and develop richer and more refined ways of engaging with the university sector over time, the experience of collaboration should enable academics and their industrial collaborators to converge in attitudes, learning to share common norms and arrive at a mutual understanding about the nature of the collaboration and the research process" (Bruneel et al. 2010: 860).

As it is defined, it is mutual, value-added, experiential and about sharing.

Teaching and research have been regarded as the main roles and responsibilities of the universities since they were established. However, currently, universities

\footnotetext{
*Instructor, PhD, Hacettepe University, Ankara, Turkey.

†Professor, TED University, Ankara, Turkey.
} 
find themselves in an extraordinary role known as the 'Third Mission', referring to focusing on the societal issues and their collaboration with the industry as their stakeholders. Universities can contribute to economic development through both training necessary human resources and research and development activities (Filippakou and Williams 2014, Findlow and Hayes 2016, Jessop 2017). Besides this, in our age universities face the forces of the entrepreneurial behaviors. This brings about the concept of 'Entrepreneurial University' (Etkowitz and Zhou 2008). Based on these changes in global higher education institutions, Slaughter and Rhoades (2004) developed a theory of academic capitalism, which identifies and criticizes this organizational shift in these institutions and their responses to market pressures. In the current literature, there has been a debate going on about academic capitalism.

In Turkey, entrepreneurial behaviors and resource-seeking activities across higher education were encouraged at the end of the 1980s as a result of a neoliberal economic environment. Turkish universities started to participate in market-like behaviors through the technology transfer centers and technocenters. Therefore, Turkish universities are required to restructure and re-organize themselves regarding their new role in 'entrepreneurship' and neoliberal politics in higher education known as 'academic capitalism'. Amongst recent reflections on academic capitalism and entrepreneurialism, this article engages with the current transformation of higher education in Turkey.

\section{Theoretical Background}

'Academic Capitalism' is a framework to define the activities emerging as a result of entrepreneurial and commercialized educational politics in universities due to global economic forces. In addition, it asserts all the values, aspects and artifacts influencing the way academia works, researches and governs (Collyer 2015, Marshall 2016). Slaughter and Rhoades (2004) defined four constructs for entrepreneurship education as interstitial organizations, intermediating organizations, new circuits of knowledge, and enhanced managerial capacities. Interstitial organizations are defined as the units or departments to connect faculty members and students in the universities with the market actors. Intermediating organizations are organizations that have the mission to encourage and accelerate the entrepreneurship programs - such as Turkish Technoparks Development Association - which focus on increasing the entrepreneurial activities in Turkey. Additionally, enhanced managerial capacities involve the professionals who are not faculty members but who facilitate market-like behaviors in higher education institutions. All these activities lead to the formation of new circuits of knowledge between universities and the other agents involved (Mars and Ginter 2012). This brings about another term, knowledge regime, which refers to the collaborative production of knowledge among universities, governments and markets. These are the consequences of an entrepreneurial university model by Clark (2008) and a Triple Helix Model by Etkowitz and Leydesdorff (1995). As it is understood from the name of the model, it establishes 
another role for the university within entrepreneurialism, in addition to research and education. While education and research are both traditional roles, entrepreneurialism is a new aspect for universities. Entrepreneurial universities involve all three roles because they promote transferring knowledge in the university into the industry (Slaughter and Leslie as cited in Delanty 2001, Filippakou and Williams 2014).

In the university context, this concept refers to providing a ground in which they can turn the knowledge accumulated into a product (Clark 2008, Etkowitz and Zhou 2008, Delanty 2001). To acquire this role, Clark (1998b) highlighted the five main aspects of entrepreneurial universities as a strengthened steering core, an expanded developmental periphery, a diversified funding base, a stimulated academic heartland and an integrated entrepreneurial culture. In steering core, referring to the structural and organizational mechanism, the administration should be sensitive to change and flexible to adaptations in a diverse world. Moreover, it is expected from them to react to these changes properly. In an expanded developmental periphery, it is stated that the administration of the university should have different units, besides traditional ones such as research and development units, like incubators and technocenters. $A$ diversified funding base points out the importance of variety in the financial resources of the university so that the university can sustain its activities and act independently. The last two aspects - a stimulated academic heartland and an integrated entrepreneurial culture - refer to the cultural acceptance of entrepreneurship and the confirmation of the staff in the university. The current organizational culture of the university should be harmonized with the cultural aspects of entrepreneurialism. This harmonization also causes the diversification of the academic culture valuing tangible products rather than abstract knowledge, public good rather than generating revenues, and ownership of knowledge (Hurt 2012). This also leads to blurring the boundaries between the market and the academy (Reitz 2017), the ownership of the intellectual properties (Slaughter and Rhoades 2009, as cited in Hurt 2012), and changes in academic culture.

Clark (1998a, 2008), as the father of the entrepreneurial university, identified the main characteristics of the entrepreneurial university: continuous innovation, variety in funding, strengthening the administration's focus on change, structuring necessary interdisciplinary research centers, sensitivity towards social problems, internalizing the entrepreneurial university and sustainable transformation. All of them can be considered as pathways for the entrepreneurial university to follow, which cannot be achieved by short-term goals, but in the long-run should be followed in a consistent manner.

The collaboration between university, industry and government can obviously be depicted in the Triple Helix Model, the most-frequently used model for conceptualizing this collaboration, considering almost all the stakeholders, partners and possible features. This model consists of three main elements: actors, organizational structure and rules and regulations. The term 'actor' accounts for the university, industry and government, which have additional roles besides their traditional ones. The organizational structure describes the units transferring researches into products or information that can be used for the benefits of society. 
The last element is concerned with the boundaries and the tasks of the spheres (Etkowitz and Leydesdorff 1995). This model has been implemented in various countries, but mainly in U.S.A and England. In Turkey, this model has been implemented since the 1990s (Kiper 2010).

In the Triple Helix model, the university-industry relationship is considered continuous, and interconnected interaction among all three shareholders can take the role of the other. For instance, incubators reflect the entrepreneurialism for universities; research and development centers in industry indicate education; and the government is a financial provider for these activities. There is no clear cut among these three, and they can partially take the role of others (Etkowitz 2003, Slaughter and Cantwell 2012).

When these issues are considered, it is obviously seen that the universities in Turkey have been struggling to transform their traditional structure into an entrepreneurial one (Dayioglu-Ocal 2016). They face some challenges, such as resistance from faculty members, infrastructural problems cultural barriers, changes in the mission and roles of units, hybrid organizations (Mars and Ginter 2012), "threatening the production of public knowledge", the administration of the universities, and the working conditions of the faculty members (Filippakou and Williams 2014, Collyer 2015).

\section{Background of Academic Capitalism in Turkey}

In Turkey, the university-industry relationship is one of the most pressing current issues since the 1980s. This can be easily seen in the Turkish National Development Plans, underlying the targets and aims of Turkey in the following five to seven years. Moreover, there have been several references to the universityindustry collaboration activities starting from the fifth one publicized in 1985 (DPT 1985). The university-industry collaboration was referred to in the process of setting up the technology transfer offices, establishing and legalizing techno centers, running these centers, defining the research and development studies (DPT 1990). Since the 2000s, university-industry relations have been highly valued, and some considerable improvements have already taken place in Turkey (DPT 2000).

For example, the Law of Technology Improvement Regions and the Implementation Regulation of Technology Improvement Regions have provided some privileges to start-up and spin-off companies in the technocenters and helped the establishment of technocenters in universities, triggering industryuniversity collaborations, which was similar to the Bayh Dole Act of 1980 in USA. To promote them, research and development companies take part in the technocenters. Also, they either work as a department of the well-known companies to develop innovative products or they are owned by the faculty members to transform their research findings into products (Scott 2004, Zaharia and Gibert 2005). To conclude, university-industry relations in Turkey have accelerated with the consolidation of technocenters to initiate innovation and collaboration and to promote the third mission of universities. 
Furthermore, since 2012 Turkish universities have been evaluated regarding the innovation indicators by The Scientific and Technological Research Council of Turkey (TUBITAK 2016). These indicators have five dimensions and 23 markers. The five dimensions involve the scientific and technological research competency, the pool for intellectual property, collaboration and interaction, culture of entrepreneurialism and innovation, and contribution to economy and commercialization. Each dimension has its own items. The first dimension has the number of scientific publications, the number of citations, the number of projects supported by the research and development activities, and innovation. The second one involves the number of patenting applications, of patenting documents, of documents on beneficial model/industrial designing and of international patenting applications.

The third one is the number of research-development and innovation projects in the university-industry link, the amount of funding provided by these projects in university-industry link, the number of the international research- development and innovation projects, and the number of the faculty member and student in exchange programs. The fourth one focuses on the number of entrepreneurial, technology management and innovation, the number of full-time staff working at Technology Transfer Office, Technocenter, incubators, the existence of Technology Transfer Office, and the number of training programs organized on entrepreneurial, technology management and innovation. The final dimension deals with the number of companies owned by faculty members, the number of companies owned by the graduates of the university, the number of the faculty members employed in the companies at Technocenter and incubators, and the number of patents licensed/beneficial for models/industrial designs. All these indicators have a reference to university-industry linkage and to what extent the university is successful enough to realize this. In the recent future, these lists are going to be considered as a sign for the ranking of the universities.

Though Turkey is in the first stage of this process, there are some researchers already working on this. Okay (2009) found that $43 \%$ of the faculty members did not participate in activities regarding university-industry linkage activities, and $57 \%$ of them did not work in any unit involved in the service of these relations. Furthermore, it is pointed out in the same study that the linkage was usually on organizing courses, seminars or training activities by the faculty members. Bayrak and Halis (2003: 66) carried out a study on both the faculty members and the industry representatives. In so doing, they concluded that the main reasons for this insufficient collaboration are lack of communication and reliability between two parties, which was explained with the phrase of "waiting for something without taking any actions". It is obvious that Turkish universities have been in the process of transformation to become more entrepreneurial and more collaborative, but there have been some challenges (Dayioglu-Ocal 2016). This brings academic capitalism into Turkish universities as a result of all these neoliberal politics beginning in the 1980s (Slaughter and Cantwell 2012, Baltodano 2012). 


\section{Scope and Perspectives}

This article intends to scrutinize the findings of a previously conducted study in the context of the recent developments in academic capitalism. Also, the interactional model suggested in the same study deals with regarding the knowledge production and transferring the knowledge into other. Thus, this paper is based on the secondary data analysis of the qualitative research conducted by Dayioglu-Ocal (2011).

The participants of this qualitative study included the owners of fifteen research and development companies in the educational field at the technocenters of universities in Ankara. The profiles of the owners were regarded in terms of gender, age, level of education and their motives. Two of the owners were women, whereas the others were all men. Their ages varied from 32 to 40 . In terms of their level of education, all had graduate degrees. The number of owners who held master degrees was nine, while the number of researchers with a doctoral degree was six. Four of them had their masters in the field of Curriculum Design, three of them in the field of Computer Education and Educational Technology, while two of them held their masters in the field of measurement and evaluation. Three Ph.D holders had their degrees in Computer Education and Educational Technology, whereas the others were graduates of the Department of the Curriculum Design.

Five of them worked as research assistants or instructors during their graduate studies, while the others pursued their studies outside the university. All of them were directing research and development projects in the field of education, such as designing interactive software programs for education, software for assessing academic achievement levels within and between the schools, elearning modules, and software for artificial intelligence in measurement and evaluation programs in Turkish context. All of them were located in the technocenters in three leading universities in Ankara, Turkey.

The data collection instrument was a semi-structured interview form (Patton 2002). However, during the interviews, some additional questions, if needed, were asked to clarify the issues expressed by the participants (Patton 2002). The interviews took place face-to-face with the participants between the dates of October 1 and December 10, 2011 during the researcher's visits to the companies' offices. In the first step, all the data gathered were transcribed. After that, the key words in the data were identified and they were evaluated and turned into codes. Those codes were converted into the themes (Strauss and Corbin 1990). Even though the study was seven years ago, higher education has still been struggling and trying to find a way for themselves regarding the entrepreneurship policies. Therefore, a renewed reflection on this study is still relevant. In this article the data have been revisited considering academic capitalism, entrepreneurialism and current changes in Turkey (Dayioglu-Ocal 2011, 2013).

In academic literature, it is commonly agreed by scholars that the social sciences are less favorable fields (Kauppinen 2015, Delanty 2001) and under the attack of academic capitalism; social scientists are faced with reductions in 
their researches (Hackett 2014). The statement uttered by one of the participants in the study (Dayioglu-Ocal 2011: 71) is as follows:

What is considered as a research and development activity is usually concrete. Here "concrete" refers to develop a "product", or an innovative activity. For example, when we design a process for a school through an innovative approach, it cannot be regarded as a research and development activity. Even it is possible to get a response "this is not a research and development activity", which is a prejudice. In the field of education, research and development is different from other fields since the researchers have limited alternatives as developing an educational software, publishing the results of the research on the impact of the educational material developed on the learners, teachers and others, or disseminating the results of the products. In short, this educational process is difficult to be shown as research and development.

Moreover, the participants complained about having fewer chances with researchers and faculty members, though they were located inside the technocenters. Therefore, they added that they could not find any reason to stay inside the university campus areas. Finally, they all consider this as a problem for not establishing proper synergic relations. The participants $(n=12)$ agreed their discomfort being ignored. One of them expressed (Dayioglu-Ocal 2011: 77):

"We can thus see a problem: graduate students experience their education in the closed system of the university. In the market, it is required for the academicians to know other aspects to consider whether their graduate projects can be put into the practice. In other words, we need to sit down and negotiate about it. A student may have a great idea for a dissertation, but it could have marketing problems. This must be properly considered".

Accordingly, academia and business are two diverse worlds. In business, the products and processes have commercial values and in knowledge economy, knowledge is a commodity (Kim 2017, Ellis et al. 2014, Mendoza 2007, 2008a, 2008b, 2015, Mclure 2016). However, in academia, knowledge has scientific value the aim of which is to contribute to the field, the public and humanity. In the knowledge economy, the researches in the universities have the potential values to be turned into market products and this causes challenges for the intellectual property and the secrecy of the researches conducted (Jessop 2017; Marshall 2016). This is also one of the findings of the study conducted by the authors in 2011. In this study, the participants stated that the universities are traditional organizations and the businesses are the ones running faster in time without having any other choice. This is an indication of the universities' challenges in a global sense by "attempting to emulate the values and practices of global academic capitalism" (Kremakova 2016: 30). As a result, the academicians are considered the objects of the entrepreneurial efforts of colleges and universities (Collyer 2015, Schulze-Cleven and Olson 2017) in addition to their identity in the institutions. 
In terms of sales and marketing, of course this brought about a problem for academic entrepreneurs to deal with sales and marketing. As Reitz (2017: 877) expressed, "Although academic institutions are not likely to turn into capitalist enterprises, they are restructured through mechanisms of status production, which change the social constitution of knowledge itself". Marketization is a way of disseminating the product in commerce, whereas in academia publicizing and publishing are the ways of dissemination (Findlow and Hayes 2016, Jessop 2017). Therefore, the academic entrepreneurs have little idea and knowledge to use the right channel for their products and sometimes even they have to give up that product as they could not find a place in the market (Mendoza 2015, Slaughter and Cantwell 2012). The study (Dayioglu-Ocal 2011, 2013) mentioned that "faculty members produce some products but as they have no idea about how it can be seen in the market, this product should be kept as a finding of the academic research".

Considering the diverse values between business and academia, the biggest challenge is making these two parties run together. The place of academia is considered as the ivory tower, where only the members of that society are allowed to get in. The knowledge economy and its impacts have caused universities to enact entrepreneurial shifts from that place to the engines of the economy (Moore et al. 2011, Baltodano 2012). However, this paradigm shift in higher education is not easy in cultural sense (Boggio et al. 2016, Szelenyi as cited in Mclure 2016). The study (Dayioglu-Ocal 2011, 2013) had a striking finding where the participants defined the faculty members as the individuals who were not welcoming people outside academia, which brings about the difficulties for academia and business world in the collaboration. One of the participants in the study (Dayioglu-Ocal 2011: 96) expressed his experience as below:

"When we directly contact the faculty members, they will disregard us. I have an experience: In 2008, we attended a conference as a presenter. There I met many faculty members form different universities. They were in attitude of excluding me and made me feel "I was not one of them". I felt they considered me as if I were trying to deceive them or plagiarize their ideas. In our context, faculty members and we, as the experts in business are two complementary agents. We are in the need of the knowledge of the faculty member. They need to be aware of the business context and what is happening there".

In this quotation, "I was not one of them" as a statement is striking to visualize the gap between the faculty members and these people (Mclure 2016). The use of the pronoun "We" and "They" signifies the gap between these two parties. However, in the Triple Helix model (Etkowitz 2003) and the entrepreneurial university (Clark 1998b) these two are considered as collaborative partners with the government. It is expected from them to keep their traditional roles, but also harmonize themselves. For this reason, it is an obvious finding that the faculty members can show resistance towards the change of their roles 
and positions in higher education as a result of academic capitalist regime. Thus, though this collaboration is not inevitable, administrators and managers should focus on the changes. In Turkey's case, "Technocenters" can be the key organizations to foster this collaboration by involving in the faculty members and entrepreneurs in some project activities (Meneghel et al. 2004, DayiogluOcal 2011, 2013).

\section{The Interactional Model}

All three main components of Triple Helix Model are included in this model (Figure 1), however, industry in the theory is named as market due to the scope of the study. It is possible to call it 'industry' in the fields of engineering and science. However, the participants were conducting the research and development activities in the field of education. That is why they needed to understand the market conditions and discover the needs systematically. As the findings of the case study indicated, these companies needed support from the experts or the members at the colleges of business and administration of the universities about how to find their own way. Therefore, the administrators of the technocenters should have contact with the faculty member from these colleges and provide support for the companies in terms of marketing and business issues.

The government, the other component, is substantially responsible for providing the necessary regulations and laws based on the reflection gathered from the stakeholders. The significance of the study lies in the fact that this is one of the preliminary researches proposing a model for the university-industry linkage in the field of higher education policy. Since Turkish universities are still in the process of strengthening their university-industry collaborative activities under the organizations of technocenters, the government has to organize some incentives to support the companies and to provide required regulations, such as intellectual property (Etkowitz 2003, Dayioglu-Ocal 2011, 2013).

The last component is the university. The model suggests the vice president of the university as the representative of the university in charge of the work of university-industry collaborations. He or she should be equipped with the necessary responsibilities and the rights of decision-making on all matters related to university-industry collaboration activities, including the technocenters. The representative of the university is expected to deal with problems and set up a trustworthy, sound and valid project among the parties by bridging the faculties, departments and units. The results of the study indicated that there was a gap between the faculty and the companies to collaborate and work together (Dayioglu-Ocal 2011, 2013). Moreover, the companies running research and development were lacking knowledge about the real business world (DayiogluOcal 2011, 2013). The other sub-component is the Faculty of Education. Since the companies in the study group deal with research and development activities in the field of education, the academics in the Faculty of Education are considered their primary partners to collaborate by researching, consolidating or working together. 


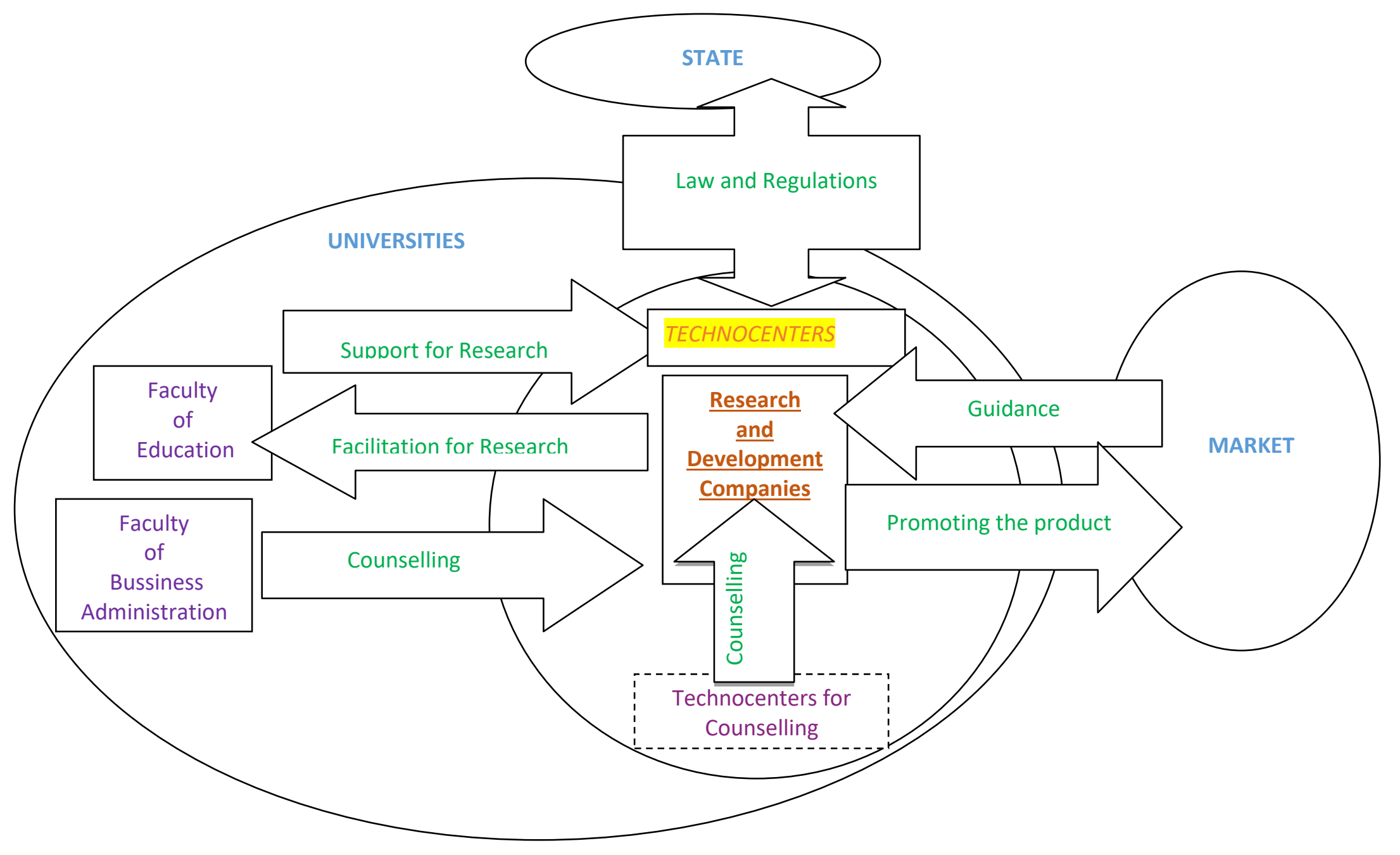


On the other hand, one of the striking results was that there has been almost no collaboration with colleges of education at universities (Dayioglu-Ocal 2011). In addition, faculty members from the colleges of business administration provide the companies counseling about how to run a company and the rules of marketing. As stated above, all the owners of the research and development companies have no background on the issues of running a company, as they are the graduates of different departments in education. Colleges of education are the units which are expected to provide knowledge and research capacities. The participants regarded that they could work together with the graduate students in their projects or dissertations (Dayioglu-Ocal 2011). For this reason, the technocenters are expected to organize some workshops and seminar where two parties meet and negotiate the issues and dimensions through which they can work together. Moreover, the administrators of these colleges should provide necessary regulations to help their academic staff collaborate and work with them. The research and development companies in the field of education are the agents who help the faculty members and researchers to apply their research findings to the market so that they can be more helpful. The participants of the study stated that the faculty members have well-planned and well-developed researches to be implemented and turned into educational products, such as software programs or training programs. However, they added that the members usually stay away from them since they do not trust them and think they may be misguided.

As a result, it is a fact that Turkish universities have been transforming into entrepreneurial universities. In this process, they are required to infuse the entrepreneurial culture into their departments, to re-structure themselves and to shift their traditional units into entrepreneurialism. The model proposed is considered as a guide for the universities that are in this process, and it is a pathway for the ones that would like to proceed to entrepreneurialism. The model implies that governments, universities and markets should work in collaboration so that the university-industry collaboration can be put into practice effectively. It can be concluded the more interaction is provided among the parties, the more "scientist-entrepreneurs" (Moore et al. 2011) will gain benefits. These benefits can push the higher education institution to find more wellestablished and balanced places.

\section{Implications and Future Researches}

The implications of this article can be listed as follows:

1. Turkish universities are faced with tough changes in the spirit of academia besides their solutions towards funding. Market-like values have integrated into tertiary education by blurring the traditional academic values. Even nowadays, it is so frequent to hear the graduate students in the science and technology field are conducting their dissertations together with companies. However, in social sciences this integration is not at the desired level (Moore et al. 2011, Billig 2013). 
2. Social sciences in Turkish universities are also under threat of commercialization - even though they have not been comprehended well enough (Baltodano 2012). The funding for the social sciences lessens over time when the current funding resources, such as TUBITAK and EU funds, are regarded. Slaughter and Cantwell (2012) defined this as "uneven development" and explained these fields as the ones criticizing neoliberalism and academic capitalism, which puts them into a disadvantaged position.

3. Academic capitalism - as it has happened in other countries - manipulates the roles of the faculty members to behave like businesspeople. However, they are actors in their own field constructing themselves continuously, struggling for their autonomy, legitimacy, power and status (Mendoza 2008b). Besides, they have to become "capitalist entrepreneurs" to survive in this system (Collyer 2015, Ellis et al. 2014, Filippakou and Williams 2014).

4. Under the pressure of the knowledge economy, knowledge has a commercial value. This leads to a dilemma for the faculty members to share their researches and findings with the people. They have trust problems towards business people (Dayioglu-Ocal 2011, 2013, Mendoza 2015, Jessop 2017). Higher education institutions as the major producers of high-level information have been asking their academic staff to produce more credible information (Reitz 2017, Baltodano 2012, SchulzeCleven and Olson 2017).

As a result, higher education institutions in Turkey, namely universities, are in the process of transforming themselves, owing to the global and neoliberal drives of politics. It is not possible for the faculty members to keep their traditional roles as they are and to continue in academia. It is essential for each institution to set up their own methods for protecting their academic staff but also for creating opportunities for them to be entrepreneurs.

\section{Declaration of Competing Interest}

This article is the product of SEÇİL DAYIOĞLU ÖCAL's Ph.D dissertation research conducted under the guidance of Prof. Dr. YÜKSEL KAVAK. He was the advisor of this dissertation, whom really supported and facilitate me a lot to complete it. Regarding the article, we, as the authors, declare that we have no competing interests. 


\section{Bibliography}

Baltodano M (2012) Neoliberalism and the demise of public education: the corporatization of schools of education. International Journal of Qualitative Studies in Education 25 (4): 487-507.

Bayrak S, Halis M (2003) Öğretim elemanları ve sanayici açısından üniversite- sanayi işbirliğinin değerlendirilmesi. [Evaluation of university-industry cooperation in terms of instructors and industrialists]. Sosyal Bilimler Dergisi. Manas Üniversitesi Sosyal Bilimler Dergisi 5: 64-85.

Billig M (2013) Academic Words and Academic Capitalism. Athenea Digital 13(1): 712. Available at http://bit.ly/2p8BQG2.

Boggio A, Ballabeni A, Hemenway D (2016) Basic research and knowledge production modes: A view from the Harvard Medical School. Science, Tehcnology and Human Values 41(2): 163-193.

Bruneel J, D' Este P, Salter A (2010) Investigating the factors that diminish the barriers to university-industry collaboration. Research Policy 39: 858-868.

Clark BR (2008) On Higher Education. Baltimore: The John Hopkins University Press.

Clark BR (1998a) Creating Entrepreneurial Universities: Organizational Pathways of Transformation. Oxford: Pergamon.

Clark BR (1998b) The entrepreneurial university: Demand and response. Tertiary Education and Management 4(1): 99-116.

Collyer FM (2015) Practices of conformity and resistance in the marketization of the academy: Bourdieu, professionalism and academic capitalism. Critical Studies in Education

Dayioglu-Ocal S (2011) Üniversiteler Ile Teknokentlerdeki Eğitim Arge Şirketleri Arasindaki Ilişsilere Yönelik Bir Model Önerisi. [A Model Proposal for the Relations between the Universities and the Educational Research and Development Companies at the Technocenters]. Doctoral Thesis. Ankara, Turkey.

Dayioglu-Ocal S (2013) Problems between universities and educational research and development companies at technocenters. Journal of Education and Future 4: 87107.

Dayioglu-Ocal (2016) Transformation towards entrepreneurialism in Turkish universities: A dilemma and critical evaluation. In ŞŞ Erçetin (eds.) Chaos, Complexity and Leadership 2014, 243-250. Springer. DOI 10.1007/978-3-319-18693-1.

Delanty G (2001) Challenging Knowledge The University In The Society. USA: Open University Press.

DPT (1985) Beşinci Beş Yıllık Kalkınma Planı (1985-1989). [The Fifth Five-Year Development Plan (1985-1989)]. Retrieved from http://bit.ly/2p8AGdE. [Accessed 16 November 2017].

DPT (1990) Altıncı Beş Yıllık Kalkınma Planı (1990-1994). [The Sixth Five-Year Development Plan (1990-1994)]. Retrieved from http://bit.ly/2FvnvP9. [Accessed 16 November 2017].

DPT (2000) Sekizinci Beş Ylllık Kalkınma Planı (2001-2005). [The Eighth Five-Year Development Plan (2001-2005)]. Retrieved from http://bit.ly/2HrdLlk. [Accessed 16 November 2017].

Ellis V, McNicholl J, Blake A, McNally J (2014) Academic work and proletarianisation: A study of higher education-based teacher educators. Teaching and Teacher Education 40: 33-43.

Etkowitz H, Zhou C (2008) Introduction to special issue building entrepreneurial university: A Global Perspective. Science and Public Policy 35(9): 627- 635. 
Etkowitz H (2003) Innovation in innovation: The triple helix of university- industrygovernment relations. Social Science Information 42: 293-337.

Etzkowitz H, Leydesdorff L (1995) The triple helix-university-industry-government relations: A laboratory for knowledge-based economic development. EASST Review 14(1): 9- 14

Filippakou O, Williams G (2014) Academic Capitalism and entrepreneurial universities as a new paradigm of 'Development'. Open Review of Educational Research 1(1): 70-83.

Findlow S, Hayes AL (2016) Transnational academic capitalism in the Arab Gulf: balancing global and local, and public and private, capitals. British Journal of Sociology of Education 37(1): 110-128. DOI: 10.1080/01425692. 2015.1100531.

Hackett EJ (2014) Academic capitalism. Science, Technology \& Human Values 39(5): 635-638.

Hurt E (2012) The marketization of higher education. College Literature 39(2): 121-132.

Jessop B (2017) Varieties of academic capitalism and entrepreneurial universities. Higher Education 73: 853-870. DOI 10.1007/s10734-017-0120-6.

Kauppinen I (2015) Towards a theory of transnational academic capitalism. British Journal of Sociology of Education 36(2): 336-353.

Kim T (2017) Academic mobility, transnational identity capital, and stratification under conditions of academic capitalism. Higher Education 73(6): 981-997. DOI 10.1007/ s10734-017-0118-0.

Kiper M (2010) Dünyada ve Türkiye'de Üniversite-Sanayi Işbirliği ve Bu Kapsamda Üniversite-Sanayi Ortak Araştırma Merkezleri Programı (ÜSAMP). [UniversityIndustry Cooperation in the World and in Turkey and University-Industry Joint Research Centers Research Program within this Context]. Ankara: Türkiye Teknoloji Geliştirme Vakfi.

Kremakova M (2016) The "new spirit of academic capitalism": Can scientists create generative critique from within? Theory of Science 1: 27-51.

Mars MM, Ginter MB (2012) Academic innovation and autonomy: an exploration of entrepreneurship education within american community colleges and the academic capitalist context. Community College Review 40(1): 75-95. DOI: 10.1177/0091 552111436209.

Marshall GS (2016) The university in the knowledge economy: academic capitalism and its implications for doctoral students in public administration. Administrative Theory \& Praxis 38(4): 296-304. DOI: 10.1080/10841806. 2016.1239398.

Mendoza P (2007) Academic capitalism and doctoral student socialization: A Case Study. The Journal of Higher Education 78 (1): 71-96.

Mendoza P (2008a) Socialization to the Academic Culture. Revista de Estudios Sociales, $31,104-117$.

Mendoza P (2008b) Academic Capitalism and academic culture: a case study. Eductaion Policy analysis Archives 16 (23).

Mendoza P (2015) Industry -academia linkages: Lessons from empirical studies and recommendations for future inquiry. In JC Smart, MB Paulsen (eds) Handbook of Higher Education: Research and Theory 30: 469-523.

Meneghel S, Mello D, Gomes E, Brisolla S (2004) The university-industry relationship in brazil. International Journal of Technology Management and Sustainable Development 2(3): 173-190.

Mclure KR (2016) Building the innovative and entrepreneurial university: an institutional case study of administrative academic capitalism. The Journal of Higher Education 87(4): 516-543. DOI: https://doi.org/10.1353/jhe.2016. 0023.

Moore K, Kleinman DL, Hess D (2011) Science and neoliberal globalization: political 
sociological approach. Theory and Society 40(5): 505-532. DOI 10.1007/s11186011-9147-3.

Okay, Ş. 2009. Pamukkale üniversitesi öğretim elemanlarının üniversite-sanayi işbirliği çalışmalarına bakışları üzerinde bir alan araştırması. [A fieldwork on the view of pamukkale university instructors on university-industry cooperation studies]. Teknik Bilimler Meslek Yüksekokulu Teknik-Online Dergi 8 (2): 94- 111.

Patton MQ (2002) Qualitative Research and Evaluation Methods (3 Edition). Newbury Park, CA: Sage Publications, Inc.

Reitz T (2017) Academic hierarchies in neo-feudal capitalism: How status competition process trust and facilitates the appropriation of knowledge. Higher Education 73: 871-886. DOI: 0.1007/s10734-017-0115-3.

Schulze-Cleven T, Olson JR (20170 Worlds of higher education transformed: Toward varieties of academic capitalism Higher Education 73: 813-831. DOI10.1007/s 10734-017-01233.

Slaughter S, Rhoades G (2004) Academic Capitalism and the New Economy: Markets, State, and Higher Education. Baltimore and London: The John Hopkins University Press.

Slaughter S, Cantwell B (2012) Transatlantic moves to the market: The United States and the European Union. Higher Education 63: 583-606.

Scott S (2004) Academic Entrepreneurship University Spin-Offs and Wealth Creation. Cheltham and Northampton: Edward Elger Press.

Strauss AL, Corbin J (1990) Basics of Qualitative Research: Grounded Theory Procedures and Techniques. Newbury Park, CA: Sage.

TÜBİTAK (2016) Entrepreneurial and Innovative University Index. Retrieved from http://bit.ly/2Fwmgzn. [Accessed 11 November 2016].

Teknoloji Geliştirme Bölgeleri Derneği (TGBD). Retrieved from http://bit.ly/2IkveNy [Accessed_14 August 2017].

Zaharia SE, Gibert E (2005) The Entrepreneurial University in the Knowledge Society. Higher Education in Europe 30(1): 31- 40. 
